\section{Relationships between substrate and the mobilization of reserve with temperature during seed germination of Ormosia coarctata Jack.}

\author{
Luciane Pereira Reis ${ }^{1}$ iD, Eduardo Euclydes de Lima e Borges ${ }^{1 *}$ (D) , Genaina \\ Aparecida de Souza² ${ }^{\text {ID }}$, Danielle S. Brito ${ }^{3}$
}

ABSTRACT: Seed germination studies provide essential information for biodiversity conservation and ecological restoration programs. This work aimed to investigate the relationship between the substrates and the mobilization of reserves during germination of Ormosia coarctata seeds under different temperatures. Samples were collected every $48 \mathrm{~h}$ for up to $240 \mathrm{~h}$ for quantification of lipids, soluble sugars, starch, and soluble proteins. The optimum temperature range for germination was 25 to $35^{\circ} \mathrm{C}$. The highest germination percentages were obtained using sand or paper roll. Carbohydrate, lipid, and protein contents decreased during germination, regardless of temperature.

Index terms: temperature change, hydration, substrates, Fabaceae.

\section{Relações do substrato e da mobilização de reservas com a temperatura na germinação de sementes de Ormosia coarctata Jack.}

RESUMO: Estudos da germinação de sementes fornecem informações essenciais para a conservação da biodiversidade e programas de restauração ecológica. Este trabalho teve como objetivo investigar as relações entre os substratos e a mobilização de reservas durante a germinação de sementes de Ormosia coarctata sob diferentes temperaturas. As amostras foram coletadas a cada $48 \mathrm{~h}$ por até $240 \mathrm{~h}$ para quantificação de lipídios, açúcares solúveis, amido e proteínas solúveis. A faixa ótima de temperatura para germinação foi de 25 a $35{ }^{\circ} \mathrm{C}$. As maiores porcentagens de germinação foram obtidas com areia ou rolo de papel. Os teores de carboidratos, lipídios e proteínas diminuíram durante a germinação, independentemente da temperatura.

Termos para indexação: mudança de temperatura, hidratação, substratos, Fabaceae.
Journal of Seed Science, v.42, e202042017, 2020

http://dx.doi.org/10.1590/2317$1545 v 42223509$
*Corresponding author
E-mail: elborges.ufv@ufv.br

Received: 05/03/2019. Accepted: 04/20/2020.

${ }^{1}$ Departamento de Engenharia Florestal, Universidade Federal de Viçosa, 36570-900 - Viçosa, MG, Brasil.

${ }^{2}$ Empresa de Pesquisa Agropecuária de Minas Gerais (EPAMIG), 36571-000 Viçosa, MG, Brasil.

${ }^{3}$ Departamento de Biologia Geral, Universidade Federal de Viçosa, 36570-900 - Viçosa, MG, Brasil. 


\section{INTRODUCTION}

Ormosia coarctata Jacks. belongs to the family Fabaceae, subfamily Papilionoideae. The tree is distributed throughout the states of Amazonas, Pará, Roraima, and Mato Grosso in Brazil, where it is popularly known as "tento" or "olho de cabra" (Campos Filho and Sartorelli, 2015). Ormosia sp has a diversity of chemical compounds important for the industry such as alkaloids, isoflavones, lecithins, and proanthocyanidins (Fernandes et al., 2011; Pouny et al., 2014). It also presents a potential for use in landscape projects, recovery of degraded areas, and handicrafts (Carneiro et al., 1998; Lorenzi, 2002; Frausin et al., 2008).

Germination is a biochemical and physiological process that begins with water uptake by the seed and the activation of metabolism. From this stage onwards, germination is influenced by seed viability and environmental factors. The ecophysiological responses of plants vary according to the conditions to which they are exposed, and one of the environmental factors that most affect germination is temperature. It influences germination speed and percentage, imbibition rate, and mobilization of storage reserves (Bewley et al., 2013). The effect of temperature on germination, however, varies among species. Acacia caven, Amburana cearensis, and Erythrina crista-galli seeds have higher germination at a constant temperature of $30{ }^{\circ} \mathrm{C}$ (Escobar et al., 2010; Guedes et al., 2010; Mello et al., 2016). Poecilanthe parviflora, Dimorphandra mollis, and Clitoria fairchildiana seeds germinate better at alternate temperatures of 25 and $30^{\circ} \mathrm{C}$ (Valadares and Paula, 2008; Pacheco et al., 2010; Alves et al., 2013).

During germination, carbohydrates, lipids, and proteins are mobilized for energy production and tissue growth. These processes are influenced by temperature regimes (Tesfay et al., 2016), as temperature affects the rate of metabolic reactions. In Melanoxylon brauna, $\alpha$-amylase activity was shown to increase during imbibition at temperatures between 25 and $30^{\circ} \mathrm{C}$ (Ataíde et al., 2016). Low germination temperatures were shown to decrease the concentration of linoleic acid in Helianthus annuus seeds (Belo et al., 2014), suggesting that the synthesis of this fatty acid was inhibited. Sugar, starch, lipid, and total protein concentrations were higher in Carica papaya seeds imbibed at constant temperature $\left(25^{\circ} \mathrm{C}\right.$ ) than at alternating temperatures (20 and $30{ }^{\circ} \mathrm{C}$ ) (Mengarda et al., 2015).

Brazilian biomes are threatened by continued deforestation. The implementation of ecosystem rehabilitation and restoration programs requires knowledge on tree propagation, particularly via seeds, which is the main mode of propagation of forest species. Information on physiological and biochemical responses of $O$. coarctata seeds to environmental conditions becomes even more relevant in the context of climate change. Therefore, this study aimed to evaluate the effect of different germinative substrates and mobilization of reserve during the germination of $O$. coarctata seeds at different temperatures.

\section{MATERIAL AND METHODS}

O. coarctata seeds were collected in Alta Floresta, Mato Grosso, Brazil. Average temperatures vary from 23 to $26{ }^{\circ} \mathrm{C}$, with maximum temperatures exceeding $40{ }^{\circ} \mathrm{C}$ (Caires and Castro, 2002). After collection, seeds were sent to the laboratory, carefully selected, and stored in fiber drums in a cold room at $5{ }^{\circ} \mathrm{C}$ and $60 \%$ relative humidity for seven months, after which the experiments were performed.

Dormancy was broken by mechanical scarification of the hilum or by chemical scarification with concentrated sulfuric acid $\left(\mathrm{H}_{2} \mathrm{SO}_{4}\right)$ for $45 \mathrm{~min}$ under constant agitation. Seeds were germinated in sand, between papers, and in paper rolls at $15,25,30,35$, and $40{ }^{\circ} \mathrm{C}$. The sand substrate was autoclaved for $2 \mathrm{~h}$ at $120^{\circ} \mathrm{C}$ before use. Sand germination tests were conducted in transparent polystyrene boxes. The treatment with two paper was carried out in $9 \mathrm{~cm}$ diameter Petri dishes. The following parameters were evaluated during germination: germination percentage, germination speed index, imbibition curve, and cotyledon reserve levels.

\section{Germination percentage}

Germination was recorded daily. Seeds were considered germinated upon radicle emergence. These data were 
used to calculate the germination percentage $(\% \mathrm{G})$ and germination speed index.

\section{Germination speed index}

The germination speed index (GSI) was determined according to Maguire (1962).

\section{Imbibition curve}

Seeds were weighed before imbibition, at $1 \mathrm{~h}$ intervals for the first $12 \mathrm{~h}$ of imbibition, at $24 \mathrm{~h}$, and then at $24 \mathrm{~h}$ intervals until $50 \%$ of the seeds germinated. At these pre-determined times, seeds were dried with paper towels, weighed, and then placed back in the wet substrate. Each treatment consisted of five replications of 20 seeds.

\section{Determination of cotyledon reserves}

Samples were collected every $48 \mathrm{~h}$ until radicle emergence was observed. Seeds germinated at $15^{\circ} \mathrm{C}$ were analyzed for up to $240 \mathrm{~h}$, whereas seeds germinated at $40{ }^{\circ} \mathrm{C}$ were analyzed for up to $96 \mathrm{~h}$. Prior to each analysis, seeds were oven dried at $45^{\circ} \mathrm{C}$ for $24 \mathrm{~h}$. The cotyledons were ground in a mill, and the dry powder was stored in hermetically sealed glass containers.

\section{Determination of lipids}

Lipid content was determined using $1 \mathrm{~g}$ of dry material. Samples were placed in filter paper thimbles, weighed, and extracted for $24 \mathrm{~h}$ with hexane in a Soxhlet apparatus. Then, thimbles were oven dried at $45^{\circ} \mathrm{C}$ for $24 \mathrm{~h}$ and weighed. Lipid content was calculated as the difference between initial and final dry weights and expressed as a percentage of the total dry weight. Four replications were used for each treatment.

\section{Determination of soluble sugars}

Soluble sugars were determined according to Buckeridge and Dietrich (1990), with modifications. After extraction, samples were oven dried at $45{ }^{\circ} \mathrm{C}$ for $24 \mathrm{~h}$ and resuspended in $1.0 \mathrm{~mL}$ of distilled water. An aliquot of the solution $(10 \mu \mathrm{L})$ was diluted in distilled water and used for quantification of soluble sugars by the phenol-sulfuric colorimetric method (Dubois et al., 1956). A standard curve was constructed using $0.01 \%(w / v)$ glucose. Five replications were used for each treatment.

\section{Determination of starch}

The solution prepared for quantification of soluble sugars was also used for starch extraction and quantification. The sample was oven dried, and $20 \mathrm{mg}$ of the resulting powder was digested for $15 \mathrm{~min}$ with $1.0 \mathrm{~mL}$ of $35 \%(\mathrm{w} / \mathrm{v}$ ) perchloric acid. After digestion, the sample was centrifuged at $10,000 \mathrm{~g}$ for $5 \mathrm{~min}$ (Passos, 1996). Starch quantification was performed using $5 \mu \mathrm{L}$ aliquots of the supernatant, according to the colorimetric method of Dubois et al. (1956). A standard curve was constructed using $0.01 \%(\mathrm{w} / \mathrm{v})$ glucose. Five replications were used for each treatment.

\section{Determination of total proteins}

Total protein content was determined by the micro-Kjeldahl method (CUNNIFF, 1995), with modifications. Defatted samples $(200 \mathrm{mg}$ ) were mixed with $1.0 \mathrm{~g}$ of digestion mixture and $5 \mathrm{~mL}$ of sulfuric acid and placed in a digestion block at $350^{\circ} \mathrm{C}$. Upon completion of the digestion process, $10 \mathrm{~mL}$ of distilled water was added to the solution. Distillation was performed in the presence of sodium hydroxide $(\mathrm{NaOH}, 1: 1 \mathrm{v} / \mathrm{v})$. The distillate was collected in an Erlenmeyer flask containing $10 \mathrm{~mL}$ of $5 \%(\mathrm{w} / \mathrm{v})$ boric acid and titrated with $0.05 \mathrm{~N}$ hydrochloric acid. The total protein content was estimated using a factor of 6.25 . Five replications were used for each treatment.

\section{Determination of monosaccharides}

Monosaccharides were extracted using the method of Blackig et al. (1996), with modifications. The dry powder 
was incubated with $80 \%(\mathrm{v} / \mathrm{v})$ ethanol for $30 \mathrm{~min}$ at $75{ }^{\circ} \mathrm{C}$, and the mixture was centrifuged at $10,000 \mathrm{~g}$ for $5 \mathrm{~min}$. The supernatants were combined and taken to dryness. Then, the powder was resuspended in $1.0 \mathrm{~mL}$ of ultrapure water, and $0.5 \mathrm{~mL}$ of this solution was used to prepare an alditol acetate solution. Quantification was performed according to Englyst and Cummings (1985) on a Shimadzu GC 14-a gas chromatograph equipped with a flame ionization detector (FID) and a Shimadzu C-R8A Chromatopac integrator. A moderately polar column coated with $50 \%$ cyanopropylphenyl and $50 \%$ dimethylsiloxane was used. The gas flow was set at $0.25 \mathrm{~mL} \cdot \mathrm{min}^{-1}$. The injector, detector, and column temperatures were respectively 2500,2200 , and $2750{ }^{\circ} \mathrm{C}$. Samples were injected with a split ratio of $1 / 40 ; 1.0 \mu \mathrm{L}$ of alditol acetate was used. Each treatment consisted of four replications.

\section{Statistical analysis}

The experiment was carried out in a $5 \times 3$ completely randomized factorial design, with five temperatures and three substrates. Treatments consisted of five replications of 20 seeds each, totaling 100 seeds per treatment. Germination percentages and GSI values were compared using Tukey's test. The level of significance was set at $p \leq 0.05$. Data were analyzed using R version 3.4.1 (R Core Team, 2017) and ExpDes package version 1.1.2 (Ferreira et al., 2013).

\section{RESULTS AND DISCUSSION}

The highest germination percentages were observed in $O$. coarctata seeds kept at 25,30 , or $35^{\circ} \mathrm{C}$ in paper roll or sand; germination in these substrates did not differ significantly $(p \leq 0.05)$ (Figure $1 \mathrm{~A})$. Seeds germinated between papers had low germination percentage and GSI at all temperatures (Figure 1B). GSI was highest at 30 and $35{ }^{\circ} \mathrm{C}$ (Figure 1B). There was no interaction effect between temperature and substrate.

The highest germination percentages and GSls were obtained using paper roll or sand as substrate (Figures $1 \mathrm{~A}$ and $1 \mathrm{~B}$ ), shows that their large contact area enabled $O$. coarctata seeds to absorb high amounts of water. A small contact area between substrate and seed might result in the rate of water loss being higher than the rate of absorption. The between paper method was unsuitable, probably because of the smaller area of contact between substrate and seed. When choosing the substrate, the shape and size of the seed must be taken into account (Brasil, 2009). M. brauna seeds (Flores et al., 2014), Inga laurina (Barrozo et al., 2013), Eugenia involucrate and Eugenia pyriformis (Gomes et al., 2016) presented higher percentages of germination in paper roll and sand. Thus, the contact area between the substrate and the seed influenced the greater water absorption and, consequently, higher germination values.
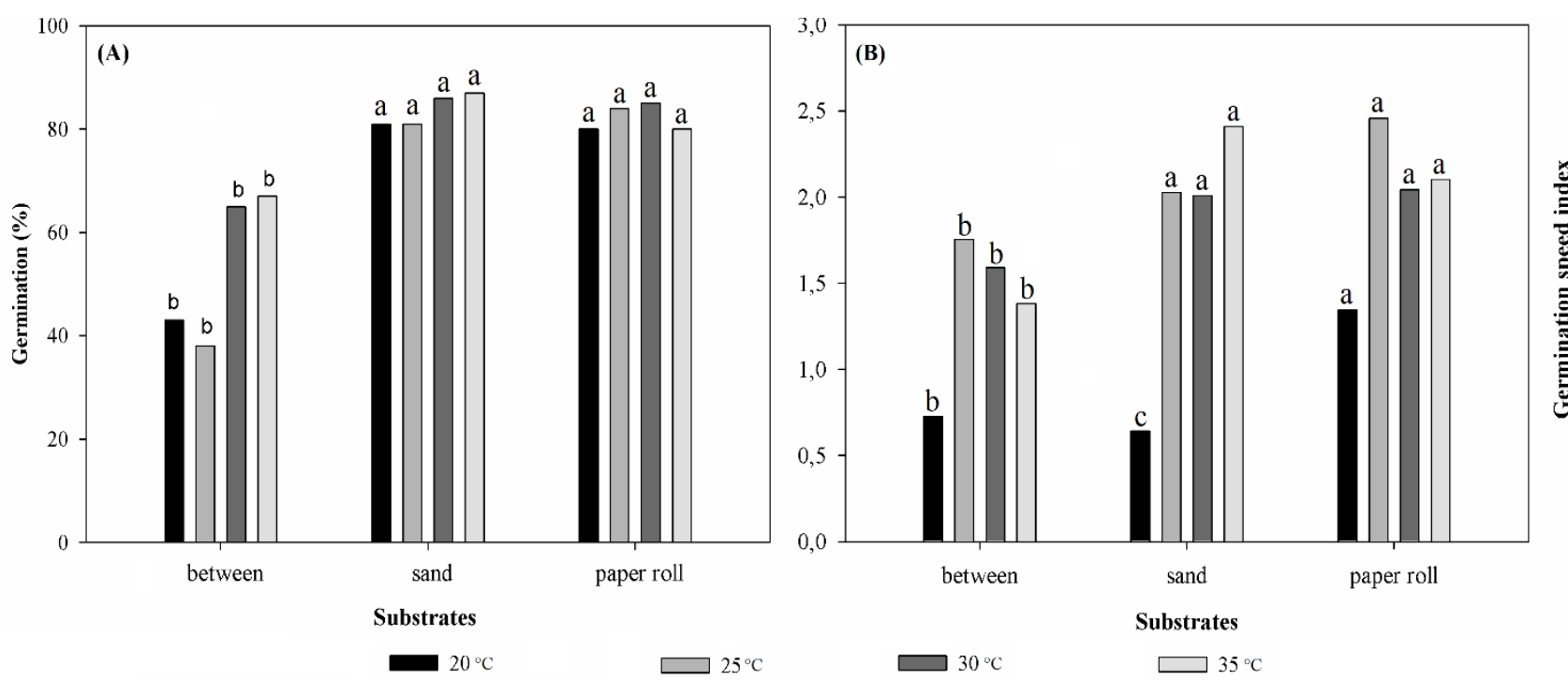

Figure 1. Germination percentage (A) and germination speed index (B) of Ormosia coarctata seeds grown in different substrates. Different letters indicate significant differences by Tukey's test $(p \leq 0.05)$. 
Seeds were not able to germinate at $15{ }^{\circ} \mathrm{C}$ during the $240 \mathrm{~h}$ experimental period. Seeds kept at $40{ }^{\circ} \mathrm{C}$ began to deteriorate and showed no signs of root protrusion after $96 \mathrm{~h}$ of imbibition. The theoretical optimal temperature was $27.8-27.9^{\circ} \mathrm{C}$, which is in agreement with the results.

The highest GSIs were achieved at 25,30 , and $35^{\circ} \mathrm{C}$. This temperature range is the same as that of the environment where seeds were collected. Oliveira et al. (2016) verified GSI values of Ormosia arborea seeds similar to those of the present study. According to the authors, $25-35{ }^{\circ} \mathrm{C}$ is the optimal germination temperature range for the species. Germination performance at a specific temperature range reflects the species adaptation to its native ecosystem, which in forest seeds may vary according to succession stage, biome, and environmental conditions (Wood and Prichard, 2003).

The rate of water uptake increased significantly with temperature, as shown by the fresh mass curves in Figure $2 \mathrm{~A}$. At 15 ${ }^{\circ} \mathrm{C}$, imbibition was slow and continuous. At all temperatures, water content increased in the first $72 \mathrm{~h}$, as water uptake at this stage is temperature independent. Imbibition occurs because of the difference in water potential between seed and substrate. In dry seeds, the matric potential is associated with the binding of water to the structural components of the cell wall and other macromolecules (Taiz et al., 2017). Imbibition initially results in the hydration of cell components, such as the cell wall and reserve polymers. The number of hydrated cells within the seed increases as imbibition proceeds (Nonogaki et al., 2010). Prior to hydration, the water potential of seed cells is more negative than that of the substrate. Upon contact, seeds rapidly absorb water.

The low and steady imbibition rate observed at $15{ }^{\circ} \mathrm{C}$ (Figure 2) might be associated with the basic metabolism of the seed or with reserve degradation. Storage reserves are used during phase 2 of imbibition, increasing the osmotic potential. However, this phenomenon did not occur because water uptake was not sufficient. Low temperatures reduce imbibition rate, enzyme activity, and energy metabolism (Luo et al., 2019). It is possible that membrane-level changes are only part of the process. Most aquaporin plasma membrane intrinsic protein (PIP) genes are down-regulated in seeds under low-temperature stress (Luo et al., 2019). Reduction in the expression of these genes results in a low number of aquaporins, thereby affecting the water absorption rate of seeds.

Low temperatures affect the reorganization of cell membranes by making the process difficult and slow (Carvalho et al., 2009). The degree of fatty acid unsaturation of membrane phospholipids is altered at low temperature. This

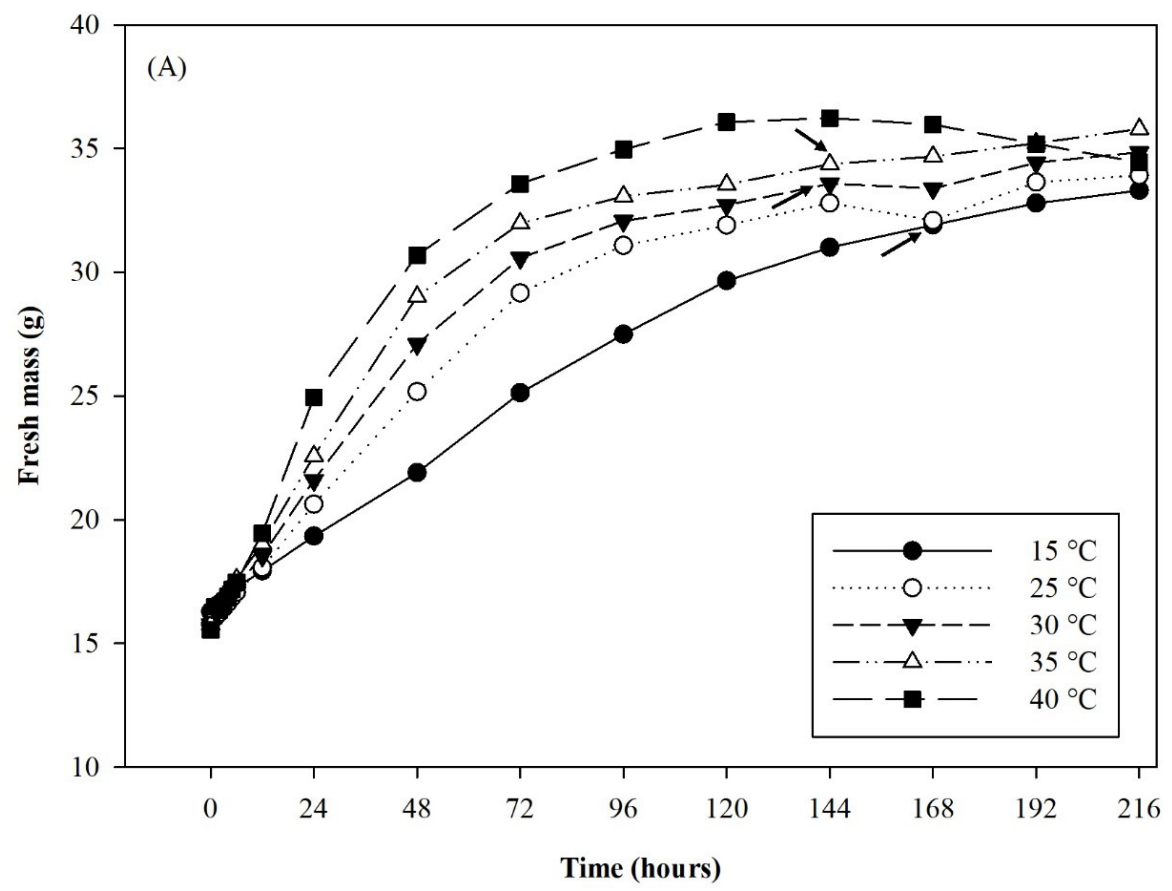

Figure 2. Imbibition curve of Ormosia coarctata seeds at different temperatures. Arrows indicate when radicle emergence occurred in $50 \%$ of the seeds. 
change affects the permeability of the membrane and its fluidity properties (Zheng et al., 2016; Noblet et al., 2017). In Zea mays seeds, low temperatures induce membrane disorganization, resulting in increased release of electrolytes into the medium and delayed germination (Noblet et al., 2017).

A three-phase imbibition pattern was observed at 25,30 , and $35^{\circ} \mathrm{C}$, with rapid water absorption at the beginning, followed by a plateau and primary root growth. Radicle emergence occurred after $192 \mathrm{~h}$ at $25^{\circ} \mathrm{C}$ and after $144 \mathrm{~h}$ at 30 and $35^{\circ} \mathrm{C}$ (Figure 2).

Phase I occurs both in viable and nonviable seeds, as this physical process is independent of metabolic activity (Bewley et al., 2013) and temperature. During phase I, the energy metabolism is resumed, and the energy needed for enzyme activation and metabolite turnover is released (Nonogaki et al., 2010). Similar results were reported for seeds of Bowdichia virgilioides and D. nigra (Albuquerque et al., 2009; Ataíde et al., 2014). Little variation in fresh seed mass was observed from 72 to $144 \mathrm{~h}$ of imbibition at 25,30 , and $35^{\circ} \mathrm{C}$. This stabilization probably occurred because of the equilibrium between seed and substrate water potentials. Guimarães et al. (2008) reported that after tissues and organelles are hydrated, membranes and enzymes become functional (phase II) and storage reserves are broken down to be used for radicle elongation.

Seeds placed to germinate at $40{ }^{\circ} \mathrm{C}$ had a higher weight gain than seeds placed at other temperatures but were deteriorated after $96 \mathrm{~h}$. The high temperature may have altered cell membrane permeability, leading to extravasation of cellular content. According to Badea and Basu (2009), high temperatures can modify components of the phospholipid bilayer. Microorganism contamination might be related to the loss of metabolites (Bewley et al., 2013), as exudates can serve as a substrate for microorganism development. In addition, the kinetic energy of particles is affected by the increase in temperature: particles become more accelerated and hydrogen bonds in macromolecules are weakened (Źróbek-Sokolnik, 2012). High temperatures can alter the tertiary structure of enzymes, which in turn reduces the rate of reactions (Źróbek-Sokolnik, 2012).

Mobilization of reserves was lowest at $15{ }^{\circ} \mathrm{C}$ because of the low metabolic activity of seeds. This condition results in low respiration rates, affecting the breakdown of seed reserves, especially of galactose, which is the main source of energy. Consequently, germination is affected, as it requires stable and functional mitochondria (Luo et al., 2019). Seeds at $40{ }^{\circ} \mathrm{C}$ had the highest consumption rate of reserves in $96 \mathrm{~h}$ of imbibition. Even though seeds germinated at other temperatures were imbibed for a longer period, $96 \mathrm{~h}$ of imbibition at $40{ }^{\circ} \mathrm{C}$ was sufficient for metabolic activation and reserve mobilization. However, these processes were interrupted at $96 \mathrm{~h}$ because seeds deteriorated. Changes in the respiratory activity of cells occur with seed deterioration, such as the release of high levels of energy (Horbach et al., 2018) caused by loss of metabolic control over the electron transport chain and oxidative phosphorylation.

Soluble sugar levels decreased during imbibition at all temperatures except $15^{\circ} \mathrm{C}$ (Figure $3 \mathrm{~A}$ ). The highest reductions occurred after $48 \mathrm{~h}$ of imbibition at 25,30 , and $35^{\circ} \mathrm{C}$. At $40^{\circ} \mathrm{C}$, the content of soluble sugars decreased by $50 \%$ in $96 \mathrm{~h}$. The consumption of soluble sugars during germination processes is attributed to energy expenditure during respiration, energy generation, and supply of embryo growth (Koch, 2004; Souza et al., 2018). Moreover, sugar consumption is also due to its metabolic signaling role. Many sugars act as a signal for the synthesis of enzymes and phytohormones (Souza et al., 2018). Therefore, its consumption may be related to molecular signaling for the different stages of tissue development (Koch, 2004). The total content of soluble sugars and reducers from two sunflower cultivars decreased during the first 24 hours (Erbaş et al., 2016). According to the authors, these reserves are the first to be used as an energy source during the initial germination period.

Xylose levels did not change significantly during imbibition at $15{ }^{\circ} \mathrm{C}$ (Figure $3 \mathrm{C}$ ). At 25,30 , and $35{ }^{\circ} \mathrm{C}$, xylose concentration decreased from 0.00126 to $0.00081 \mathrm{mg} \cdot \mathrm{g}^{-1} \mathrm{dry}$ matter after $48 \mathrm{~h}$. At $40^{\circ} \mathrm{C}$, xylose was rapidly consumed. Galactose levels decreased at all temperatures, although at a slower rate at 15 and $40{ }^{\circ} \mathrm{C}$ (Figure 3D). At 25, 30, and $35^{\circ} \mathrm{C}$, galactose was depleted after $144 \mathrm{~h}$ of imbibition. Seeds germinated at 25,30 , and $35^{\circ} \mathrm{C}$ showed similar variation in the levels of xylose and galactose. Galactose was completely depleted toward the end of imbibition, whereas xylose was still detected. These results demonstrate that monosaccharides are preferentially broken down, regardless of the 
presence of oligosaccharides. Xylose and galactose were consumed or released at a higher rate in seeds imbibed at $40{ }^{\circ} \mathrm{C}$, probably because of the degradation of cell membranes toward the end of imbibition. Thus, two processes occurred during hydration of $O$. coarctata seeds at $40{ }^{\circ} \mathrm{C}$. First, seed reserves were broken down, as shown by the increase in metabolic activity; then, reserves were released to the medium as a result of thermal damage.

Glucose was not detected at 25,30 , or $35{ }^{\circ} \mathrm{C}$ (data not shown). However, this monosaccharide was present in seeds imbibed for $144 \mathrm{~h}$ at $15{ }^{\circ} \mathrm{C}$ and for $48 \mathrm{~h}$ at $40{ }^{\circ} \mathrm{C}$ (data not shown). These results may be explained by the partial isomerization of galactose. At $15{ }^{\circ} \mathrm{C}$, increased glucose levels were attributed to low metabolic activity to and, at 40 ${ }^{\circ} \mathrm{C}$ seed death. The not detection of glucose during the germination of $O$. coarctata seeds may be related to its use for the production of sucrose in embryonic tissues. In Cedrela fissilis, glucose was detected only during the early stages of
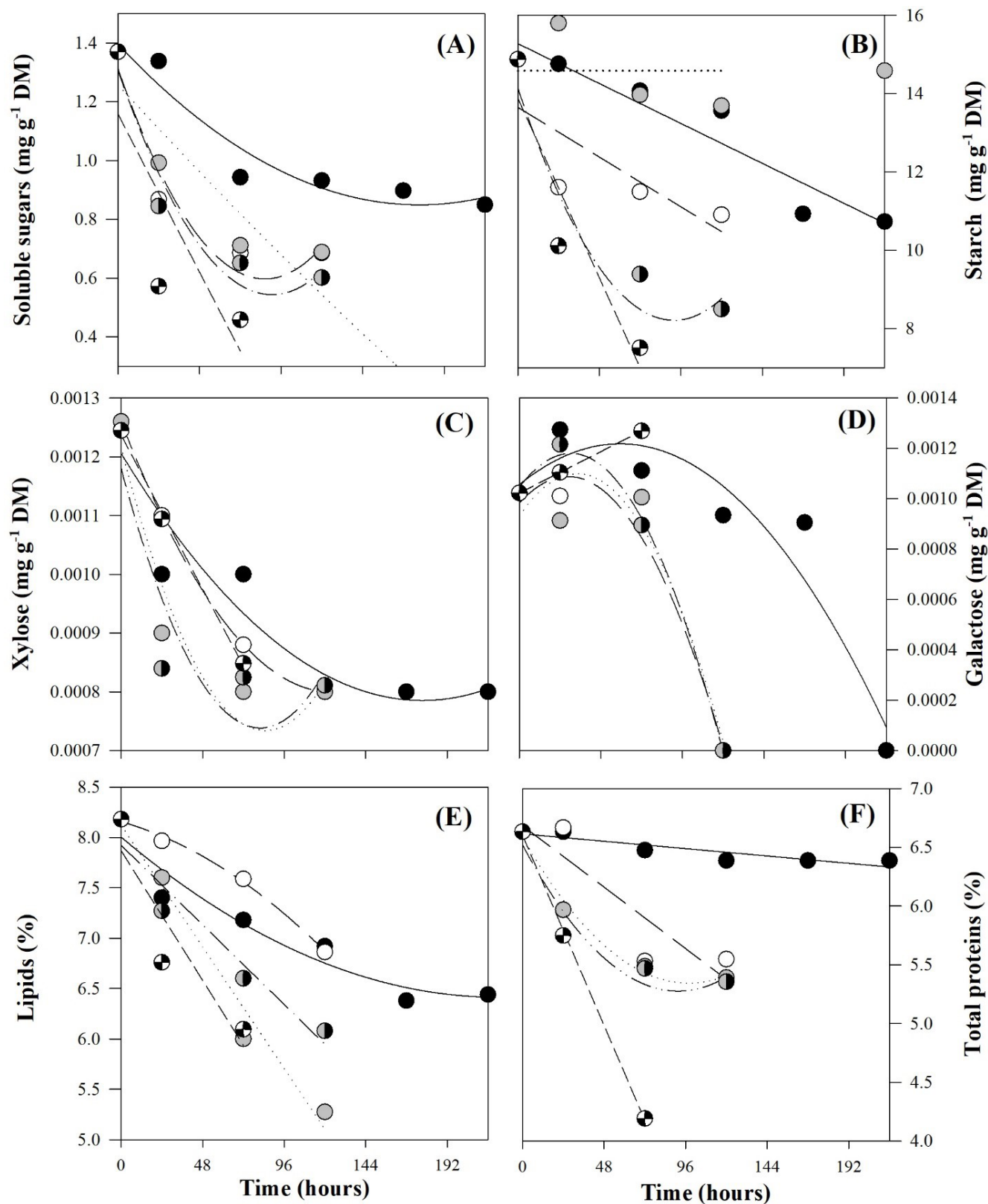

$\bullet 15^{\circ} \mathrm{C} \quad 025^{\circ} \mathrm{C} \quad \bigcirc 30^{\circ} \mathrm{C} \quad 035^{\circ} \mathrm{C} \quad 40{ }^{\circ} \mathrm{C}$

Figure 3. Soluble sugar (A), starch (B), xylose (C), galactose (D), lipid (E), and total protein contents $(F)$ in Ormosia coarctata seeds during germination at different temperatures. 
seedling development (Aragão et al., 2015). In Sebastina virgata seeds, glucose is formed during the development of the seedlings in relatively high amounts (Tonini et al., 2010). With the development of the primary root, the degradation of wall polysaccharides is released through the degradation of $A B A$, consequently sucrose and glucose increase (Tonini et al., 2010). Alternatively, monosaccharides may leave the embryo or cotyledons and are retained in the membrane or seed coat, as observed by Borges et al. (2002) in Platymiscium pubescens seeds.

The mobilization pattern of starch differed according to the germination temperature. Seeds imbibed at $15{ }^{\circ} \mathrm{C}$ showed no changes in starch concentration with time (Figure 3B). At $40^{\circ} \mathrm{C}$, starch levels decreased rapidly after $48 \mathrm{~h}$. The decrease in carbohydrate levels in seeds germinated at optimal temperatures $\left(25-35^{\circ} \mathrm{C}\right)$ indicates that there was a high mobilization of starch. Thus, soluble sugars together with starch reserves indicate degradation to obtain fast energy for embryo growtn.

Lipid levels varied with time of imbibition at all temperatures (Figure 3E). O. coarctata seeds initially contained $8.2 \%$ lipids. Lipid mobilization was slower at $15^{\circ} \mathrm{C}$. At 25,30 , and $35^{\circ} \mathrm{C}$, lipid levels decreased by $2.6,7.9$, and $11.1 \%$, respectively. At $40{ }^{\circ} \mathrm{C}$, the lipid content decreased continuously as the cotyledons deteriorated. The oil stored in the seeds in the form of triacylglycerols plays an important role in the growth of the embryo, providing energy and carbon skeletons (Knauer et al., 2013). Most seeds consume first the reserves of lower metabolic expenditure for your use (Bewley et al. 2013). However, this behavior depends on the type of seed, the amount of reserves, and the speed of germination (Bewley et al. 2013).

Lipid mobilization was relatively lower than that of the other reserves. Variation in lipid levels was similar among the different germination temperatures. Mobilization of lipid reserves is more intense after germination (Hooks et al., 2010). Free fatty acids were probably used for germination instead of triglycerides. Low lipid mobilization can be associated with the low energy requirement during germination. To be converted into carbohydrates, lipids must first be broken down by lipases and then degraded through the $\beta$-oxidation and glyoxylate pathways (Taiz et al., 2017). Because they are highly reduced molecules, lipids have high energy density and can easily supply the energy needed in the early phases of seed hydration.

The initial protein content was $16.6 \%$. Protein levels were affected by imbibition time and temperature (Figure $3 \mathrm{~F}$ ). At $15^{\circ} \mathrm{C}$, the total protein content remained relatively stable for up to $72 \mathrm{~h}$. After $96 \mathrm{~h}$ of imbibition, protein levels decreased by $2.3,16.6,17.2$, and $17.5 \%$ in seeds soaked at $15,25,30$, and $35{ }^{\circ} \mathrm{C}$, respectively. At $40{ }^{\circ} \mathrm{C}$, seeds showed a continuous reduction in protein content. The total protein level was $36.8 \%$ lower after $96 \mathrm{~h}$ of imbibition. During imbibition, stored proteins are proteolyzed by different enzymes (Bewley et al., 2013) resulting in free amino acids that are used for the synthesis of protein components and, therefore, essential for the development of the embryo (Erbaş et al., 2016).

Unfavorable temperature conditions can negatively affect reserve mobilization, thereby impairing germination (Mengarda et al., 2015). Ataíde et al. (2016), however, observed no differences in reserve mobilization in seeds germinated at 15 or $25^{\circ} \mathrm{C}$. The authors reported that soluble carbohydrates, starch, and protein levels decreased while lipid levels showed little variation.

$O$. coarctata seeds are composed mainly of cotyledons, as the embryo has a reduced size. Thus, we evaluated the levels of cotyledon reserves. Considering that the embryo has little demand for reserves at the beginning of germination, we assumed that the decrease in reserve levels was due to cotyledon respiration or exudation.

\section{CONCLUSIONS}

Paper roll and sand were the best substrates for 0 . coarctata seeds germination. The optimal temperature range was $25-35^{\circ} \mathrm{C}$. Carbohydrate, lipid, and protein reserves decreased at all temperatures. Mobilization patterns of soluble sugars, xylose, and galactose were similar in seeds germinated at 25,30 , and $35^{\circ} \mathrm{C}$. Glucose was detected in 0 . coarctata seeds at 15 and $40^{\circ} \mathrm{C}$, temperatures that are not optimal temperatures for germination. This monosaccharide was not present in seeds germinated at other temperatures. 


\section{ACKNOWLEDGMENTS}

This work was supported by CNPQ, CAPES (Pro-Amazon Project) and FAPEMIG.

\section{REFERENCES}

ALBUQUERQUE, K. S.; GUIMARÃES, R.M.; ALMEIDA, I.F.; CLEMENTE, A.C.S. Alterações fisiológicas e bioquímicas durante a embebição de sementes de sucupira-preta (Bowdichia virgilioides Kunth.). Revista Brasileira de Sementes, v. 31, n. 1, p. 12-19, 2009. https://doi.org/10.1590/S0101-31222009000100028

ALVES, E.U.; ALVES, M.M.; BRUNO, R.L.A.; SILVA, K.R.G.; BARROZO, L.M.; SANTOS-MOURA, S.S.; CARDOSO, E.A. Germinação e vigor de sementes de Clitoria fairchildiana Howard (Fabaceae) em função da coloração do tegumento e temperaturas. Bioscience Journal, v. 29, n. 1, p. 216-223, 2013. http://www.seer.ufu.br/index.php/biosciencejournal/article/view/13886.

ARAGÃO, V.P.M.; NAVARRO, B.V.; PASSAMANI, L.Z.; MACEDO, A.F., FLOH, E.I.S.; SILVEIRA, V.; SANTA-CATARINA, C. Free amino acids, polyamines, soluble sugars and proteins during seed germination and early seedling growth of Cedrela fissilis Vellozo (Meliaceae), an endangered hardwood species from the Atlantic Forest in Brazil. Plant Physiology, v. 27, n. 2, p. 157-169, 2015. https://link. springer.com/article/10.1007/s40626-015-0041-7

ATAÍDE, G.M.; BORGES, E. E. L.; FLORES, A.V.; CASTRO, R.V.O. Avaliação preliminar da embebição de sementes de jacarandá-dabahia. Pesquisa Florestal Brasileira, v. 34, n. 78, p. 133-139, 2014. https://pfb.cnpf.embrapa.br/pfb3/index.php/pfb/article/view/520

ATAÍDE, G.M.; BORGES, E.E.L.; LEITE FILHO, A.T. Alterações fisiológicas e biométricas em sementes de Melanoxylon brauna Schott durante a germinação em diferentes temperaturas. Revista Árvore, v. 40, n. 1, p. 61-70, 2016. https://doi.org/10.1590/010067622016000100007

BADEA, C.; BASU, S.K. The effect of low temperature on metabolism of membrane lipids in plants and associated gene expression. Plant Omics Journal, v. 2, n. 2, p. 78-84, 2009. https://www.pomics.com/Saikat_2_2_2009_78_84.pdf

BARROZO, L.M.; ALVES, E.U.; SILVA, R.S.; ANJOS NETO, A.P.; SANTOS, M.D.M.S.; SILVA, B. F. Substratos e temperaturas para testes de germinação e vigor de sementes de Inga laurina (Sw.) Bioscience Journal, v. 30, n. 3, 2013. http://www.seer.ufu.br/index.php/ biosciencejournal/article/view/18037

BELO, R.G.; TOGNETTI, J.; BENECH-ARNOLD, R.; IZQUIERDO, N.G. Germination responses to temperature and water potential as affected by seed oil composition in sunflower. Industrial Crops and Products, v. 62, p. 537-544, 2014. https://www.sciencedirect. com/science/article/pii/S0926669014005743

BEWLEY, J.D.; BRADFORD, K.J.; HILHORST, H.W.M.; NONOGAKI, H. Seeds: physiology of development, germination and dormancy. 3 ed.: Springer, 2013. p. 392.

BLACKIG, M.; CORBNEAU, F.; GRZESIK, M.; GUY, P.; CÔME, D. Carbohydrate metabolism in the developing and maturing wheat embryo in relation to its desiccation tolerance. Journal Experimental Botany, v. 47, n. 295, p. 161-169, 1996. https://academic.oup. com/jxb/article/47/2/161/457737

BORGES, E.E.L.; PERES, S.C.J.G.A.; BORGES, R.C.G.; REZENDE, S.T.; GARCIA, S.R. Comportamento fisiológico de sementes osmocondicionadas de Platymiscium pubescens Micheli (tamboril-da-mata). Revista Árvore, v. 26, n. 5, p. 603-613, 2002. http:// www.scielo.br/scielo.php?pid=S0100-67622002000500011\&script=sci_arttext\&tlng=pt

BRASIL. Ministério da Agricultura, Pecuária e Abastecimento. Regras para análise de sementes. Brasília: MAPA/ACS, 2009. 395p. http://www.agricultura.gov.br/arq_editor/file/2946_regras_analise_sementes.pdf

BUCKERIDGE, M.S.; DIETRICH, S.M.C. Galactomanans from Brazilian legume seeds. Revista Brasileira de Botânica, v. 13, p. 109-112, 1990. http://www.scielo.br/scielo.php?script=sci_nlinks\&ref=000085\&pid=S0100-6762200200050001000005\&Ing=en

CAIRES, M.S.; CASTRO, J.G.D. Levantamento dos agrotóxicos usados por produtores rurais do município de Alta Floresta Mato Grosso. Revista de Biologia e Ciências da Terra, v. 2, n. 1, 2002. https://www.redalyc.org/html/500/50020103/

CAMPOS FILHO, E.M.; SARTORELLI, P.A.R. Guia de identificação de espécies-chave para restauração florestal na região de Altos Teles Pires Mato Grosso. The nature conservancy, p. 248, 2015. https://www.tnc.org.br/content/dam/tnc/nature/en/documents/ brasil/guia-mt.pdf 
CARNEIRO, M.A.C.; SIQUEIRA, J.O.; MOREIRA, F.M.S.; CARVALHO, D.; BOTELHO, S.A.; JUNIOR, O.J.S. Micorriza arbuscular em espécies arbóreas e arbustivas de ocorrência no sudeste do Brasil. Cerne, v.4, n.1, p.129-145, 1998. http://www.bibliotecaflorestal. ufv.br:80/handle/123456789/18292

CARVALHO, L.F.; SEDIYAMA, C.S.; REIS, M.S.; DIAS, D.C.F.S.; MOREIRA, M.A. Influence of soaking temperature of soybean seeds in the electrical conductivity test to evaluate physiological quality. Revista Brasileira de Sementes. v. 31, p.9-17, 2009. https://doi. org/10.1590/S0101-31222009000100001

CUNNIFF, P. Official methods of analysis of Aoac International. 16a ed., AOAC, 1995. p. 1141.

DUBOIS, M.; GILLES, K.A.; HAMILTON, J.K.; REBERS, P.A.; SMITH, F. Colorimetric method for determination of sugars and related substances. Annalitical Chemistry, v. 28, p. 350-356, 1956. https://pubs.acs.org/doi/abs/10.1021/ac60111a017

ENGLYST, H.N.; CUMMINGS, J.H. Digestion of the polysaccharides of some cereal foods in the human small intestine. American Journal of Clinical Nutrition, v. 42, p. 778-787, 1985. https://academic.oup.com/ajcn/article-abstract/42/5/778/4692039

ERBAŞ, S.; TONGUÇ, M.; ŞANLI, A. Mobilization of seed reserves during germination and early seedling growth of two sunflower cultivars. Journal of Applied Botany and Food Quality, v. 89, p. 217-222, 2016. https://www.researchgate.net/publication/304254241

ESCOBAR, T.A.; PEDROSO, V.M.; BONOW, R.N.; SCHWENGBER, E.B. Superação de dormência e temperaturas para germinação de sementes de Acacia caven (Mol.) Mol. (espinilho). Revista Brasileira de Sementes, v. 32, n. 2 p. 124-130, 2010. http://www.scielo. br/scielo.php?pid=S0101-31222010000200015\&script=sci_abstract\&tlng=pt

FERNANDES, A.V.; RAMOS, M.V.; GONÇALVES, J.F.C.; MARANHÃO, P.A.C.; CHEVREUIL, L.R.; SOUZA, L.A.G. Seeds of amazonian Fabaceae as a source of new lectins. Brazilian Journal of Plant Physiology, v. 23, n. 3, p. 237-244, 2011. http://www.scielo.br/scielo. php?script=sci_arttext\&pid=S1677-04202011000300008

FERREIRA, E.B.; CAVALCANTI, P.P.; NOGUEIRA, D. A. ExpDes: Experimental Designs pacakge. R package version 1.1.2., 2013. https:// cran.r-project.org/web/packages/ExpDes/index.html

FLORES, A.V.; BORGES, E. E. L.; GUIMARÃES, V. M.; GONÇALVES, J. F. C.; ATAÍDE, C. M.; BARROS, D. P. Atividade enzimática durante a germinação de sementes de Melanoxylon brauna Schott sob diferentes temperaturas. Cerne, v. 20, n. 2, p. 401-408, 2014. http:// www.scielo.br/scielo.php?pid=S0104-77602014000300009\&script=sci_abstract\&tlng=pt

FRAUSIN, G.; TRUJILLO, E.; CORREA, M.; GONZÁLEZ, V. Seeds used in handicraft manufactured by an Emberá-Katío indigenous population displaced by violence in Colombia. Cadalsia, v. 30, n. 2, p. 315-323, 2008. http://www.scielo.org.co/scielo.php?script=sci_ arttext\&pid=S0366-52322008000200005.

GOMES, J.P.; OLIVEIRA, L.M.; FERREIRA, P.I.; BATISTA, F. Substratos e temperaturas para teste de germinação em sementes de Myrtaceae.Ciência Florestal,v.26, p.285--293,2016. http://www.scielo.br/scielo.php?pid=S1980-50982016000100285\&script=sci_ abstract\&tlng=pt.

GUEDES, R.S.; ALVES, E.U.; GONÇALVES, E.P.; VIANA, J.S.; FRANÇA, P.R.C.; LIMA, C.R. Umedecimento do substrato e temperatura na germinação e vigor de sementes de Amburana cearensis (All.) A.C. Smith. Revista Brasileira de Sementes, v. 32, n. 3, p. 116-122, 2010. http://www.scielo.br/scielo.php?pid=S0101-31222010000300013\&script=sci_abstract\&tlng=es.

GUIMARÃES, M.A.; DIAS, D.F.S; LOUREIRO, M.E. Hidratação de sementes. Revista Trópica - Ciências Agrárias e Biológicas, v. 2, n. 1, p. 31-39, 2008. https://www.researchgate.net/profile/Marcelo_Guimaraes/publication/246044401_Hidratacao_de_sementes/ links/0046351d8dd48d5620000000.pdf.

HOOKS, M. A.; ALLEN, E.; WATTIS, J. A. D. Modelling the peroxisomal carbon leak during lipid mobilization in Arabidopsis. Biochemical Society Transactions, v. 38, n. 5, p.1230-1233, 2010. http://www.biochemsoctrans.org/content/38/5/1230.

HORBACH, M.A.; DRANSKI, J.A.L.; MALAVASI, U.C.; MALAVASI, M.M. Physiological quality and seed respiration of primed Jatropha curcas seeds. Acta Botanica Brasilica, v. 32, n. 1, p. 63-69, 2018. https://doi.org/10.1590/0102-33062017abb0231

KNAUER, S.; HOLT, A.L.; RUBIO-SOMOZA, I. A protodermal miR394 signal defines a region of stem cell competence in the Arabidopsis shoot meristem. Developmental Cell, v. 24, p. 125-132, 2013. https://www.ncbi.nlm.nih.gov/pubmed/23333352

$\mathrm{KOCH}, \mathrm{K}$. Sucrose metabolism: regulatory mechanisms and pivotal roles in sugar sensing and plant development. Current Opinion in Plant Biology. v.7, p.235-246, 2004. https://www.sciencedirect.com/science/article/pii/S1369526604000469.

LORENZI, H. Árvores brasileiras: manual de identificação e cultivo de plantas arbóreas nativas do Brasil. Nova Odessa: Instituto Plantarum, v.2, 2002. 368 p. 
LUO, T.; XIAN, M.; ZHANG, C.; ZHANG, C.; HU, L.; XU, Z. Associating transcriptional regulation for rapid germination of rapeseed (Brassica napus L.) under low temperature stress through weighted gene co-expression network analysis. Scientific Reports, v. 9, n. 1, p. 55, 2019. https://www.nature.com/articles/s41598-018-37099-0.

MAGUIRE, J.D. Speed of germination aid in selection and evaluation for seedling emergence and vigor. Crop Science, v. 2, n. 2, p.176-77, 1962. https://dl.sciencesocieties.org/publications/cs/abstracts/2/2/CS0020020176.

MELLO, L.M.; CANTOS, A.A.; MENEGHELLO, G.E.; SILVA, A.C.S.; VILLELA, F.A. Superação de dormência e influência da temperatura, substrato e fotoperíodo na germinação de sementes de Erythrina crista-galli L. (Fabaceae). Revista Thema, [S.I.], v. 13, n. 3, p. 30-37, 2016. http://revistathema.ifsul.edu.br/index.php/thema/article/view/371.

MENGARDA, L.H.G.; LOPES, J.C.A.; RODRIGO, S.A.; ZANOTTI, R.F.; MANHONE, P.R. Alternating temperature and accelerated aging in mobilization of reserves during germination of Carica papaya L. seeds. Journal of Seed Science, v. 37, n. 1, p. 16-25, 2015. http:// www.scielo.br/scielo.php?script=sci_arttext\&pid=S2317-15372015000100016.

NOBLET, A.; LEYMARIE, J.; BAILLY, C. Chilling temperature remodels phospholipidome of Zea mays seeds during imbibition. Scientific Reports, 7, 8886, 2017. https://www.nature.com/articles/s41598-017-08904-z.

NONOGAKI, H.; BASSEL, G.W.; BEWLEY, J. D. Germination - still a mystery. Plant Science. v.179, n.6, p.574-581, 2010. https://www. sciencedirect.com/science/article/pii/S0168945210000403.

OLIVEIRA, A.K.M.; SOUZA, J.S.; CARVALHO, J.M.B.; SOUZA, S.A.; BOCCHESE, R.A. Germinação de sementes e crescimento de Ormosia arborea em diferentes temperaturas e substratos. Gaia Scientia, v. 10, n. 4, 2016. http://www.periodicos.ufpb.br/ojs/ index.php/gaia/article/view/26413

PACHECO, M.V.; MATTEI, V.L.; MATOS, V.P.; SENA, L.H.D.M. Germination and vigor of Dimorphandra mollis Benth. seeds under different temperatures and substrates. Revista Árvore, v.34, n. 2, p. 205-213, 2010. https://doi.org/10.1590/S0100-67622010000200002

PASSOS, L.P. Métodos analíticos e laboratoriais em fisiologia vegetal. Coronel Pacheco: EMBRAPA-CNPGL, 1996.223 p.

POUNY, I.; BATUT, M.; VENDIER, L.; DAVID, B.; YI, S.; SAUTEL, F.; ARIMONDO, P.B.; MASSIOT, G. Cytisine-like alkaloids from Ormosia hosiei Hemsl. \& E. H. Wilson. Phytochemistry, v. 107, p. 97-101, 2014. https://www.ncbi.nlm.nih.gov/pubmed/25172516

R Core Team. A Language and Environment for Statistical Computing, 2017. https://www.R-project.org/

SOUZA, G.A.; DIAS, D.C.F.S.; PIMENTA, T.M.; ALMEIDA, A.L.; PICOLI, E.A.T.; ALVARENGA, A.P.; SILVA, J.C.F. Sugar metabolism and developmental stages of rubber tree (Hevea brasiliensis L.) seeds. Physiologia Plantarum, v.162, p.495-505, 2018. https:// onlinelibrary.wiley.com/doi/abs/10.1111/ppl.12650.

TAIZ, L.; ZEIGER, E.; MØLLER, I.M.; MURPHY, A. Fisiologia e desenvolvimento vegetal. 6.ed. RTMED, 2017. 858p.

TESFAY, S.Z.; MODI, A.T.; MOHAMMED, F. The effect of temperature in moringa seed phytochemical compounds and carbohydrate mobilization. South African Journal of Botany, v. 102, p. 190-196, 2016. https://www.sciencedirect.com/science/article/pii/ S0254629915003269.

TONINI, P.P.; PURGATTO, E.; BUCKERIDGE, M.S. Effects of abscisic acid, ethylene and sugars on the mobilization of storage proteins and carbohydrates in seeds of the tropical tree Sesbania virgata (Leguminosae). Annals of Botany. v. 106, n. 4, p.607-616, 2010. https://www.ncbi.nlm.nih.gov/pmc/articles/PMC2944982/.

VALADARES, J.; PAULA, R.C. Temperaturas para germinação de sementes de Poecilanthe parviflora Bentham (Fabaceae - Faboideae). Revista Brasileira Sementes, v. 30, n. 2, p. 164-170, 2008. https://doi.org/10.1590/S0101-31222008000200020.

WOOD, C.B., PRICHARD, H.W. Germination characteristics of fresh and dried Hyophorbe lagenicaulis seeds. Palms. v.47, p.45-50, 2003. https://eurekamag.com/research/004/177/004177232.php

ZHENG, G.; LI, L.; LI, W. Glycerolipidome responses to freezing- and chilling-induced injuries: examples in Arabidopsis and rice. $B M C$ Plant Biology, v. 16, n. 70, 2016. https://www.ncbi.nlm.nih.gov/pmc/articles/PMC4802656/.

ŹRÓBEK-SOKOLNIK, A. Temperature stress and responses of plants. In: Ahmad, P.; Prasad M.N.V. (eds). Environmental adaptations and stress tolerance of plants in the era of climate change. New York: Springer, 2012. p. 113-134. 